\title{
ANALISIS PENGARUH INTELLECTUAL CAPITAL TERHADAP FINANCIAL PERFORMANCE DENGAN COMPETITIVE ADVANTAGE SEBAGAI VARIABEL INTERVENING
}

\author{
Muzakar Isa dan Della Ariska Deviana \\ Program Studi Manajemen Universitas Muhammadiyah Surakarta \\ Jl. A. Yani Pabelan Kartasura 57108 Surakarta \\ Email: muzakar.isa@ums.ac.id
}

\begin{abstract}
Abstrak-
Penelitian ini bertujuan untuk menganalisis:(1) pengaruh intellectual capital terhadap competitive advantage; (2) pengaruh intellectual capital terhadap financial performance; (3) pengaruh mediasi hubungan antara intellectual capital dan financial performance. Teknik pengambilan sampel adalah purposive sampling dan berdasarkan kriteria yang ditentukan, sehingga diperoleh 21 perusahaan yang memenuhi kriteria. Penelitian ini termasuk kausal komparatif. Analisis yang digunakan dalam penelitian ini meliputi uji asumsi klasik, analisis regresi linier dan analisis jalur. Hasil penelitian ini menunjukkan bahwa: (1) Intellectual Capital mempunyai pengaruh positif dan signifikan terhadap Competitive Advantage; (2) Intellectual Capital mempunyai pengaruh positif dan signifikan terhadap financial performance; (3) Competitive Advantage memediasi Intellectual Capital terhadap Financial Performance.
\end{abstract}

Kata Kunci: Intelectual capital, Financial Performance, Competitive Advantage.

\begin{abstract}
The purpose of this research are to analyze: (1) influence of intellectual capital to the competitive advantage; (2) influence of intellectual capital to the financial performance; (3) the mediating effect of competitive advantage in the relationship between intellectual capital and financial performance. The technique of the sample collection was purposive sampling and based on the determined criteria, so 21 companies which have met the criteria have been selected as samples. This research was casual comparative. The analysis used in this study includes classical assumption test, liniar regression analysis and path analysis. The result of this research show that: (1) Intellectual Capital has a significant and positive effect on Competitve Advantage; (2) Intellectual Capital significantly and positively influence on Financial Performance; (3) Competitive Advantage variabel is mediated Intellectual Capital to the Financial Performance.
\end{abstract}

Keyword: Intellectual Capital, Financial Performance, Competitive Advantage

\section{PENDAHULUAN}

Perkembangan teknologi dan meningkatnya kecepatan akses informasi menyebabkan perusahaan menaikkan kapasitasnya guna memenangkan persaingan. Persaingan usaha yang semakin ketat menuntut perusahaan untuk mengubah strategi bisnis agar terus bertahan. Saat ini, banyak perusahaan masih menekankan penggunaan tangible asset. Padahal, dalam perubahan lingkungan bisnis yang cepat perusahaan bergeser mengoptimalkan intangible asset (Libyanita dan Wahidahwati, 2016)

Intangible asset yang penting bagi perusahaan adalah intellectual capital (IC).
Sawarjuwono dan Kadir (2003) menjelaskan IC merupakan gabungan dari elemen utama organisasi yang berkaitan dengan pengetahuan dan teknologi. Keberadaan IC dikenal sebagai teori berbasis sumber daya. Peran yang dimiliki modal 2 dengan para pesaing Barney (1991). IC memiliki sumbangan besar dalam peningkatan kinerja dan penciptaan nilai bagi perusahaan (Marr et al 2004).

Perusahaan harus menggeser dari fokus modal fisik yang didasarkan pada tenaga kerja (labor based bussines) menjadi IC yang menjadi karakteristik perusahaan berbasis pengetahuan untuk menciptakan nilai perusahaan (Marr et al, 2004). Perusahaan yang mampu menciptakan keunggulan 
bersaing dapat menjaga kelangsungan bisnis (going concern) dalam jangka waktu yang lama sehingga perusahaan dapat bertahan atas persaingan. Menurut M. E. Porter, (1980), strategi bersaing menghasilkan keunggulan bersaing dengan menghasilkan produk unggulan dengan biaya produksi yang lebih rendah dibanding pesaingnya. Hal ini menunjukkan bahwa competitive advantage yang terbentuk dari IC mempengaruhi financial performance.

Financial performance perusahaan mencerminkan tingkat efektivitas dan efisiensi perusahaan dalam memanfaatkan sumber daya yang tersedia untuk mencapai tujuan perusahaan. Pengukuran kinerja perlu dilakukan untuk melakukan evaluasi kinerja. Para pengguna informasi dapat menggunakan rasio keuangan untuk mengukur kinerja keuangan perusahaan seperti rasio profitabilitas, likuiditas, pasar, leverage dan aktivitas (Hanafi dan Halim, 2002). Berdasarkan rasio keuangan tersebut, rasio profitabilitas merupakan salah satu indikator kinerja keuangan yang sering digunakan dalam pengambilan keputusan. Hal ini dikarenakan rasio profitabilitas sangat cocok mengukur efektivitas dan mengevaluasi kinerja manajemen dalam menjalankan usaha bisnis dan produktivitasnya dalam mengelola aset-aset perusahaan secara keseluruhan (Gany dan Nugrahanti, 2015).

MacKinnon, (2008) menyatakan penelitian competitive advantage dalam memediasi hubungan antara IC dan financial performance masih terbatas. banyak penelitian mengenai IC mengabaikan pentingnya keunggulan bersaing pada hubungan IC dan kinerja perusahaan (Chang dan Lee, 2008). Ramadhan (2009) menelaskan tidak semua variabel IC memiliki pengaruh positif terhadap kinerja perusahaan. Ghosh dan Mondal (2009) menunjukkan bahwa modal intelektual berpengaruh positif terhadap Return on Assets, tetapi berpengaruh negatif pada ATO dan MB. Berdasarkan beberapa penelitian yang telah dilakukan menunjukkan hasil yang berbeda mengenai pengaruh IC tehadap kinerja perusahaan. Hal ini mungkin dikarenakan perbedaan perkembangan dan penggunaan teknologi akan mengakibatkan perbedaan dalam implikasi dan penggunaan IC. Selain itu implementasi IC merupakan hal yang masih baru di Indonesia (Widjanarko, 2006).

Perusahaan manufaktur merupakan salah satu sektor industri berbasis pengetahuan yang dapat menghasilkan inovasi dalam dunia bisnis. Kementrian Perindustrian di Indonesia menjelaskan bahwa sektor manufaktur tumbuh 28\%. Kenaikan ini merupakan kenaikan tertinggi kedua dari sepuluh sektor yang ada (Kemenperin, 2017). Dengan ini, penulis mengambil perusahaan manufaktur di Indonesia tahun 2012-2016 karena IC banyak diterapkan di perusahaan-perusahaan manufaktur 5 guna memberikan nilai tambah bagi perusahaan begitujuga dengan competitive advantage yang dibutuhkan oleh perusahaan, sehingga diharapkan dapat mencapai financial performance yang maksimal.

Pentingnya peranan IC dalam mewujudkan competitive advantage dan tumbuhnya kesadaran perusahaan-perusahaan di Indonesia dalam mengelola IC dengan baik untuk meningkatkan financial performance merupakan alasan pentingnya penelitian ini dilakukan. Dalam penelitian ini akan dilihat apakah IC berpengaruh terhadap financial performance perusahaan dengan keunggulan bersaing competitive advantage sebagai variabel intervening. Tujuan penelitian ini (1) menganalisis pengaruh IC terhadap Competitive Advantage, (2) menganalisis pengaruh IC terhadap Financial Performance, dan (3) menganalisis pengaruh competitive Advantage sebagai mediator hubungan antara Intellectual Capital dan Financial Performance.

\section{METODE PENELITIAN}

Penelitian ini menggunakan pendekatan kuantitatif. Menurut Radjab dan Jam'an (2017), penelitian kuantitatif didasarkan pada asumsi bahwa realitas yang menjadi sasaran penelitian berdimensi tunggal, fragmental, dan cenderung bersifat tetap sehingga dapat diprediksi, dan variabel dapat diidentifikasi dan diukur dengan alat-alat yang objektif dan baku.

Variabel dependen merupakan variabel yang menjadi fokus utama penelitian atau merupakan pusat perhatian peneliti (Suhartanto, 2014). Variabel dependen yang digunakan Kinerja keuangan. Menurut 
Pranata dalam Dewi (2011), kinerja keuangan perusahaan menunjukkan efektivitas dan efisiensi perusahaan dalam mencapai tujuannya. Return on asset (ROA) merupakan salah satu rasio profitabilitas yang mengukur efektivitas perusahaan dalam menghasilkan keuntungan dengan memanfaatkan aset yang dimiliki perusahaan. Dengan demikian, ROA menunjukkan efisiensi dan keuntungan bisnis perusahaan dalam memanfaatkan total asetnya Chen et al. (2005).

Variabel independen adalah variabel penyebab atau yang mempengaruhi variabel dependen (Suhartanto, 2014). Variabel independen dalam penelitian ini adalah intellectual capital yang diukur berdasarkan value added yang diciptakan oleh physical capital (VACA), human capital (VAHU), dan structural capital (STVA). Value added merupakan indikator yang digunakan untuk menilai kemampuan perusahaan dalam menciptakan nilai dan merupakan indikator yang paling obyektif untuk menunjukkan kemampuan perusahaan dalam penciptaan nilai (Ulum, 2008). Berikut adalah penjelasan dari pengukuran ketiga komponen tersebut (Ulum, 2008):

1. Value Added Capital Employed (VACA). Ini merupakan indikator value added (VA) yang diciptakan oleh satu unit dari physical capital. Rasio ini menunjukkan kontribusi yang dibuat oleh setiap unit $\mathrm{CE}$ terhadap value added organisasi. Semakin besar nilai VACA maka semakin baik bagi perusahaan, karena menunjukkan besarnya konstribusi yang dibuat oleh setiap unit $\mathrm{CE}$ untuk meningkatkan nilai perusahaan.

2. Value Added Human Capital (VAHU). Ini menunjukkan berapa banyak value added yang mampu dihasilkan dengan dana yang telah dikeluarkan untuk tenaga kerja. Rasio ini juga menunjukkan kontribusi yang dibuat oleh setiap rupiah yang diinvestasikan human capital (HC) untuk menciptakan nilai bagi perusahaan. Rasio ini menunjukkan seberapa banyak value added yang diperoleh perusahaan dengan dana yang dikeluarkan untuk tenaga kerja. Semakin besar nilai VAHU maka semakin baik bagi perusahaan, karena menunjukkan besarnya kemampuan human capital dalam menciptakan nilai.
3. Structural Capital Value Added (STVA). Ini menunjukkan konstribusi structural capital dalam menciptakan nilai. STVA mengukur jumlah structural capital (SC) yang dibutuhkan untuk menghasilkan 1 rupiah dari value added dan menjadi indikasi bagaimana keberhasilan SC dalam menciptakan nilai. SC 39 bukanlah ukuran independen sebagaimana $\mathrm{HC}$, tetapi dependen terhadap value creation. Maksudnya adalah semakin besar kontribusi $\mathrm{HC}$ dalam value creation, maka akan semakin kecil kontribusi SC dalam hal tersebut. Pulic juga menyatakan bahwa SC adalah VA dikurangi HC. Semakin besar nilai STVA, maka semakin besar nilai tambah dari modal struktural bagi perusahaan.

Competitive advantage digunakan sebagai variabel intervening. Best (1997) menyebutkan tiga aspek utama Competitive advantage, yaitu: (1) keunggulan biaya (cost advantage), (2) keunggulan diferensiasi (differentiation advantage), dan(3) keunggulan pemasaran (marketing advantage). Dalam paper ini, Competitive advantage diproksikan keunggulan biaya (cost advantage) (Porter, 2008). Strategi ini dilakukan oleh perusahaan yang berusaha menjadi produsen berbiaya rendah dalam industrinya.

Data yang digunakan yaitu data sekunder. Data diperoleh dari laporan keuangan tahunan (annual report) perusahaan manufaktur sektor konsumsi yang terdaftar di Bursa Efek Indonesia (BEI) dari tahun 2012 sampai dengan 2016 yang diperoleh dari website IDX (Indonesian Stock Exchange). Pengumpulan data menggunakan metode dokumentasi atau studi literature. Jogiyanto (2004) menjelaskan metode dokumentasi merupakan teknik pengumpulan data dengan cara menggunakan jurnal-jurnal, buku-buku, studi pustaka dari berbagai literatur, serta sumber-sumber lain yang berhubungan dengan penelitian.

Pengambilan Sampel berdasarkan purposivesampling. Sugiyono(2013)purposive sampling merupakan teknik pengambilan sampel dengan pertimbangan tertentu. Kriteria-kriteria yang digunakan adalah (a) Perusahaan Manufaktur sektor konsumsi yang terdaftar di Bursa Efek Indonesia selama tahun 2012-2016; (b) Perusahaan Manufaktur yang 
mempublikasikan laporan keuangan selama 5 tahun berturut-turut dari tahun 2012, 2013, 2014, 2015 dan 2016; (c) Perusahaan yang memiliki data lengkap terkait dengan variable yang akan digunakan dalam penelitian; dan (d) Perusahaan Manufaktur yang memiliki laba bersih yang positif dimasukan dalam sampel penelitian.

Analisis data menggunakan analsiis jalur (path analysis) dengan bantuan program aplikasi SPSS (Statistical and Service Solution). Alat analisis ini digunakan untuk menerangkan akibat secara langsung dan tidak langsung seperangkat variabel penyebab (Akdon, 2007). Dalam paper ini IC dapat berpengaruh langsung terhadap financial performance dan berpengaruh secara tidak langsung melalui competitive advantage kemudian ke financial performance (Ghozali, 2011).

\section{HASIL PENELITIAN DAN PEMBA- HASAN}

Penelitian ini menganalisis perusahaan sektor industri barang konsumsi. Penelitian ini mengunakan data laporan keuangan perusahaan yang diperoleh dari situs resmi Bursa Efek Indonesia (BEI), yaitu www. idx.co.id. Berdasarkan teknik purposive sampling, terdapat 17 perusahaan yang memenuhi kriteria. Dengnan ini diperoleh sampel sebanyak 85 data observasi. Data tersebut berasal dari perkalian antara jumlah perusahaan sampel 17 perusahaaan dengan periode tahun yaitu selama 5 tahun dari 20122016.

Variabel IC yang diproksi dengan Value Added Intellecual Capital (VAIC) merupakan variabel independen. Nilai VAIC minimum adalah 1,59738 dan nilai maksimum 8,53139. berdasarkan hal tersebut, nilai VAIC perusahaan sampel adalah 1,59738 - 8,53139 dengan niali rata-rata 3,4281364 . Nilai VAIC minimum dimiliki oleh perusahaan Pyridam Farma Tbk pada tahun 2016, sedangkan perusahaan yang memiliki nilai VAIC maksimum adalah Mayora Indah Tbk pada tahun 2013 dengan standar deviasi sebesar 1,71436372 .

Variabel dependen ini adalah Financial Performance yang diproksikan dengan Return On Assets (ROA). Berdasarkan perhitungan statistik deskriptif, ROA memiliki nilai minimum 0,00599 dan nilai maksimum 0,71509 serta rata-rata 0,1405966 . Hal ini menunjukkan bahwa nilai ROA perusahaan sampel adalah 0,00599 - 0,71509. Nilai ROA minimum dimiliki oleh perusahaan Indofood Sukses Makmur Tbk pada tahun 2014, sedangkan perusahaan yang memiliki nilai ROA maksimum adalah Unilever Indonesia Tbk pada tahun 2013 dengan angka standar deviasi sebesar 0,12606168.

\section{Assets Utilization Efficiency (AUE)} sebagai proksi Competitive Advantage. Besarnya AUE minimum adalah 0,07400 dan nilai maksimum 5,80479. Hal tesebut menunjukkan nilai AUE perusahaan sampel adalah berkisar antara 0,07400 - 5,80479. Besarnya nilai AUE minimum pada perusahaan Indofood Sukses Makmur Tbk pada tahun 2014, sedangkan perusahaan yang memiliki AUE maksimum adalah Kimia Farma (Persero) Tbk pada tahun 2012 dengan besar nilai rata-rata 1.5254196 dan standar deviasi sebesar 0,82851788 .

Tabel 1

Hasil Path Analysis

\begin{tabular}{cccccc}
\hline Model & V. Bebas & V. terikat & Konstanta & B & S. Error \\
\hline 1 & VAIC & AUE & $-0,028$ &,- 315 & 0,130 \\
2 & VAIC & ROA & $-1,620$ & 1,122 & 0,149 \\
& AUE & ROA & $-1,620$ & 0,522 & 0,122 \\
\hline
\end{tabular}

Sumber: Hasil Analisis Data, (2018)

Gambar 1 di bawah menjelaskan besaran nilai variance variabel competitive advantage sebesar $\mathrm{e}^{1} 0,966$. Ini berarti jumlah variabel competitive advantage tidak dijelaskan oleh $I C$ atau besarnya variabel lain diluar model terhadap competitive advantage $96,6 \%$. Berdasarkan nilai error tersebut disimpulkan bahwa tidak hanya IC yang berpengaruh terhadap competitive advantage, melainkan ada beberapa variabel atau factor lain diluar 
model penelitian ini yang berpengaruh terhadap competitive advantage.

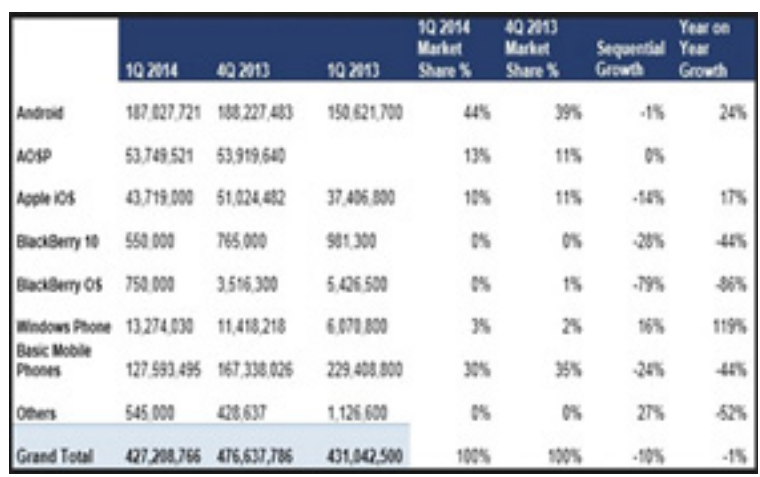

Gambar 1. Hubungan antar Variable Penelitian

Besaran nilai variance financial performance yaitu sebesar $\mathrm{e}^{2} 0,675$. Ini berarti jumlah variance variabel financial performance tidak dijelaskan oleh intellectual capital dan competitive advantage atau besarnya variabel lain diluar model terhadap financial performance adalah sebesar 6,5\%. Berdasarkan nilai tersebut disimpulkan tidak hanya intellectual capital dan competitive advantage yang berpengaruh terhadap financial performance, melainkan ada beberapa variabel atau faktor lain diluar model penelitian ini yang berpengaruh terhadap financial performance.

1. IC berpengaruh positif terhadap Competitive Advantage. Competitive advantage yang dicapai oleh perusahaan berasal dari dalam perusahaan itu sendiri berupa IC. Perusahaan yang mampu mengelola $I C$ dengan baik maka akan berpengaruh pada kondisi competitive advantage perusahaan. Menurut Sawarjuwono dan Kadir, 2003) IC merupakan jumlah dari hasil tiga elemen utama organisasi, yaitu human capital, structural capital, dan customer capital yang berkaitan dengan pengetahuan dan tekonologi yang memberikan nilai lebih untuk perusahaan berupa competitive advantage. Hal ini sesuai dengan penelitian Wang et al (2005) yang juga memperoleh hasil bahwa IC merupakan faktor penentu dari daya saing sebuah perusahaan.

2. $I C$ berpengaruh positif terhadap financial performance. Pengelolaan IC yang baik mampu meningkatkan financial performance perusahaan dimana sesuai dengan pandangan dari knowledge based theory yaitu apabila perusahaan dapat mengelola sekaligus mengembangkan sumber daya pengetahuan yang dimiliki maka dari hal itu juga dapat meningkatkan laba perusahaan. Komponen lain yang mempengaruhi financial performance merupakan bagian dari IC seperti kemampuan karyawan, tekonolgi yang canggih, hubungan dengan pemasok dan pelanggan Ismail Solihin, (2012). Hal ini juga sesuai dengan penelitian yang dilakukan oleh Chen et al (2005) dan Ulum (2008) yang menunjukkan bahwa intellectual capital berpengaruh positif terhadap financial performance perusahaan.

3. Competitive advantage memediasi hubungan antara IC dan financial performance perusahaan. Variabel intervening merupakan variabel yang memediasi hubungan antara variabel eksogen danvariabel endogen atau biasa disebut sebagai variabel antara. Berdasarkan dari perhitungan, intellectual capital berpengaruh langsung ke financial performance dan berpengaruh secara tidak langsung yaitu dari intellectual capital ke competitive advantage sebagai variabel intervening lalu ke financial performance.

\section{PENUTUP}

Hasil peneliitan menjelaskan (1) IC berpengaruh positif dan signifikan terhadap competitive advantage perusahaan sektor industri barang konsumsi yang terdaftar di BEI, (2) IC berpengaruh positif dan signifikan terhadap financial perfomance perusahaan sektor industri barang konsumsi yang terdaftar di BEI, dan (3) competitive advantage memediasi hubungan antara $I C$ dan financial performance.

Perusahaan manufaktur, khususnya bidang konsumsi perlu pelatihan untuk meningkatkan modal intelektual sehingga perusahaan meciptakan keunggulan bersaing dan menjaga kelangsungan bisnis. 


\section{DAFTAR PUSTAKA}

Ghozali, I. 2006. Aplikasi Analisis Multivariate dengan Program SPSS. Semarang: Badan Penerbit Universitas Diponegoro.

Akdon. (2007). Cara menggunakan dan memaknai analysis jalur path. Bandung: Alfabeta. Astuti, P. D., \& Sabeni, A. (2005). Hubungan Intellectual Capital dan Business Performance dengan Diamond Specification: Sebuah Perspektif Akuntansi. Simposium Nasional Akuntansi VIII Solo, 694-707.

Barney, J. B. (1991). Firm Resources and Sustained Competitive Advantage. Journal of Management. https://doi.org/10.1177/014920639101700108

Chang, S., \& Lee, M. (2008). The linkage between knowledge accumulation capability and organizational innovation. Journal of Knowledge Management, 12(1), 3-20.

Chen, M., Cheng, S., \& Hwang, Y. (2005). An empirical investigation of the relationship between intellectual capital and firms' market value and financial performance. Journal of Intellectual Capital, 6(2), 159-176. https://doi.org/10.1108/14691930510592771

Dewi, C. P. (2011). Pengaruh Intellectual Capital Terhadap Kinerja Keuangan Pada Perusahaan Manufaktur Yang Terdaftar Di Bei Tahun 2007-2009. Universitas Diponegoro. https:// doi.org/10.1108/14691930010324188

Gany, F. P. P., \& Nugrahanti, Y. W. (2015). Pengaruh Intellectual Capital Terhadap Kinerja Perusahaan Florentina. Prosiding Seminar Nasional \& Call For Papers Kinerja Perbankan, Bisnis Dan Ekonomi Indonesia Menghadapai Asean Economic Community 2015 FAKULTAS.

Ghosh, S., \& Mondal, A. (2009). Indian software and pharmaceutical sector IC and financial performance. Journal of Intellectual Capital, 10(3), 369-388. https://doi. org/10.1108/14691930910977798

Ghozali, I. (2011). Aplikasi Analisis Multivariate Dengan Program SPSS. Semarang: Badan Penerbit Universitas Diponegoro.

Hanafi, M. M., \& Halim, A. (2002). Analisis Laporan Keuangan (4th ed.). Yogyakarta: UPP STIM YKPN.

Isa, M., Setyawan, A. A., Ma'ruf, \& Nugroho, S. P. (2017). Competitiveness and Policy Development of SME Clusters, Empirical Evidence in Indonesia. Academic Journal of Business, Administration, Law and Social Sciences IIPCCL Publishing, Graz-Austria, 3(3), 45-55.

Isa, M., \& Wajdi, M. F. (2014). Membangun Konsep Modal Manusia Yang Berperanan Dalam Kinerja Pemasaran Industri Kecil. Seminar Nasional Dan Call for Paper (Sancall 2014), (Sancall), 452-464.

Isa, M \& Kusmiyati (2013), Competitiveness Model of Bioethanol Industry, Jurnal Ekonomi Pembangunan: Kajian Masalah Ekonomi dan Pembangunan, 14 (2), 2013

Josiah, N. M., \& Nyagara, N. I. (2015). Assessment of the effect of Cost Leadership Strategy on the performance of Liquefied Petroleum Gas Companies in Eldoret town, Uasin Gishu County, Kenya. International Journal of Business and Management Invention, 4(4), 1-7.

Kamukama, N., Ahiauzu, A., \& Ntayi, J. M. (2011). Competitive advantage: mediator of intellectual capital and performance. Journal of Intellectual Capital, 12(1), 152-164. 
https://doi.org/10.1108/14691931111097953

Kasmir. (2010). Pengantar Manajemen Keuangan. Jakarta: Kencana Prenada Media Group. Kemenperin. (2017). Manufaktur Ditopang Sektor Barang Konsumsi. Retrieved January 9, 2018, from http://www.kemenperin.go.id/artikel /7014/Manufaktur-Ditopang-SektorBarang-Konsumsi

Libyanita, M., \& Wahidahwati. (2016). Pengaruh Intellectual Capital Terhadap Kinerja Keuangan Dengan Competitive Advantage Sebagai Variabel Intervening. Jurnal Ilmu Dan Riset Akuntansi, 5(6), 1-19.

Madhani, P. M. (2010). Resource based view (RBV) of competitive advantage: an overview. The Icfai University Press. Retrieved from http://ssrn.com/abstract=1578704

Marr, B., Schiuma, G., \& Neely, A. (2004). Intellectual capital - defining key performance indicators for organizational knowledge assets. Business Process Management Journal, 10(5), 551-569. https://doi.org/10.1108/14637150410559225

Mussalamah, A. D. M. \& Isa Muzakar (2015) Pengaruh Earning Per Share (EPS), Debt To Equity Ratio (DER) Dan Return On Equity (ROE) Terhadap Harga Saham, BENEFIT Jurnal Managemen dan Bisnis, 2015.

Penrose, E. T. (2009). The Theory of the Growth of the Firm. Oxford: Oxford university press.

Pew Tan, H., Plowman, D., \& Hancock, P. (2007). Intellectual capital and financial returns of companies. Journal of Intellectual Capital, 8(1), 76-95. https://doi. org/10.1108/14691930710715079

Porter, M. E. (2008). Strategi Bersaing (Competitive Strategy). Tangerang: Karisma Publishing Group.

Purnomosidhi, B. (2006). Praktik Pengungkapan Modal Intelektual pada Perusahaan Publik di BEJ. Jurnal Riset Akuntansi Indonesia, 9(1), 1-20.

Radjab, E., \& Jam'an, A. (2017). Metodologi Penelitian Bisnis (1st ed.). Makassar: Lembaga Perpustakaan dan Penerbitan UMM.

Ramadhan. (2009). Pengaruh Intellectual Capital terhadap Kinerja Perusaahan Manufaktur yang Terdaftar di BEI Tahun 2002-2007. Universitas Diponegoro.

Salim, S. M., \& Karyawati, G. (2013). Pengaruh Modal Intelektual Terhadap Kinerja Keuangan. Journal of Business and Entrepreneurship, 1(2), 74-91.

Sawarjuwono, T., \& Prihatin Kadir, A. (2003). Intellectual Capital : Perlakuan, Pengukuran Dan Pelaporan. Jurnal Akuntansi \& Keuangan, 5(1), 35-57.

Soerwarno, N. (2011). Pengaruh Intellectual Capital Terhadap Kinerja Keuangan Dengan Ukuran, Jenis Industri, Dan Leverage. Majalah Ekonomi, XXI(2), 165-184.

Sugiyono. (2013). Satistika Metodologi Penelitian Kuantitatif Kualitatif dan R\&D (19th ed.). Bandung: Alfabeta.

Suhartanto, D. (2014). Metode Riset Pemasaran. Bandung: Alfabeta.

Ulum, I. (2013). iB-VAIC: Model Pengukuran Kinerja Intellectual Capital Perbankan Syariah di Indonesia. Jurnal Inferensi, 7(1), 183-204.

Ulum, I. (2015). Intellectual Capital Disclosure: Suatu Analisis Dengan Four Way Numerical Coding System. JAAI, 19(1), 39-50. 
Ulum MD, I. (2008). Intellectual Capital Performance Sektor Perbankan di Indonesia. Jurnal Akuntansi Dan Keuangan, 10(2), PP.77-84. Retrieved from http://puslit2.petra.ac.id/ ejournal/index.php/aku/article/view/17081 Wernerfelt, B. (1984). A Resource based view of the firm. Strategic Management Journal, 5(2), 171-180. https://doi.org/10.1002/ smj.4250050207

Widjanarko, I. (2006). Perbandingan Penerapan Intellectual Capital Report antara Denmark, Sweden dan Austria (Studi Kasus Systematic, Sentesia Q dan OeNB). Universitas Islam Indonesia.

Widyaningdyah, A. U., \& Aryani, Y. A. (2013). Intellectual Capital dan Keunggulan Kompetitif (Studi Empiris Perusahaan Manufaktur versi Jakarta Stock Industrial ClassificationJASICA). Jurnal Akuntansi Dan Keuangan, 15(1), 1-14. https://doi.org/10.9744/ jak.15.1.1-14

Widyaningrum, A. (2004). Modal Intelektual. Jurnal Akuntansi Dan Keuangan Indonesia, 1, 16-25. 